\title{
An Analysis of Institutional Factors Influencing Vegetable Production amongst Small-Scale Farmers in Six Vegetable Projects of the Nkonkobe Local Municipality
}

\author{
Phatela M. Raleting ${ }^{1} \&$ Ajuruchukwu $\mathrm{Obi}^{1}$ \\ ${ }^{1}$ Department of Agricultural Economics \& Extension, University of Fort Hare, Alice, South Africa \\ Correspondence: Phatela M. Raleting, Department of Agricultural Economics \& Extension, University of Fort \\ Hare, Alice Private Bag X1314, Alice, South Africa. Tel: 266-5856-2506. E-mail: mraleting@yahoo.com
}

Received: August 2, 2013 Accepted: April 27, 2015 Online Published: May 15, 2015

doi:10.5539/jas.v7n6p184 URL: http://dx.doi.org/10.5539/jas.v7n6p184

\begin{abstract}
The specific roles of institutions in mediating production and marketing within the smallholder sector have not been fully investigated and understood especially in the parts of South Africa designated independent homelands prior to the end of Apartheid. This paper investigated institutional factors influencing vegetable production in six small-scale vegetable projects in Alice town in the Nkonkobe Municipality of Eastern Cape Province of South Africa. Amidst worsening poverty in the wider society it was the intention to know how vegetable production can contribute to enhancing food security and if it is in a position to do so. Seeking some insights on effectiveness of the agrarian reforms on smallholder farmers in South Africa, the objectives of the study were to identify and explore institutional factors that influence vegetable production. The data were drawn from all the 62 farmers in the projects investigated. Descriptive analysis and binary logistic regression were employed to analyze the data and explain the patterns of interactions among the identified institutional factors influencing vegetable production. The study results revealed that some institutional factors need to be addressed to enhance vegetable production. The binary logistic results show that formal rules and informal norms are important in vegetable production. The most significant institutional variables revealed by the analysis were attributes of the formation and organizational structure of the projects, land tenure, extension service, collective action in production and marketing. The findings suggest that institutional changes in respect to aforementioned variables and other complementary institutions such as contract farming and credit access can significantly contribute to increased, efficient and sustainable vegetable production.
\end{abstract}

Keywords: institutional factors, vegetable production, livelihoods, poverty, food security

\section{Introduction}

In the literature it has been affirmed that institutional factors (both formal and informal norms) influence and shape the way individuals interact to undertake economic activity (Pejovich, 1999; Williamson, 2001; Lekovic, 2011). This would normally influence the costs of production and/or exchange (Coase, 1992; Lal, 1999). Besides, according to North (1993), the development strategy of any country is embodied within the way societies view and interpret the world around them. Since formal rules are designed and implemented by human beings, an analysis of institutional factors is necessary to gain understanding of existing institutional arrangements that would contribute to improved livelihoods and hence economic development (Adebeyi \& Obasa, 2004). Brown (2000) also supported this view by postulating that development is not based on how much one has but on how much one does with what is owned. It is, therefore, not surprising why positive policy reforms have been a success in some countries but a failure in others. Hence, the assertion that sound policy reform is a function of the interdependency of formal rules and informal norms (Hou \& Smith, 2009) comes quite handy to policy makers or development practitioners as they grope their way through the difficult and uncertain policy terrain right from the policy formulation to the implementation (Greenberg, 2010).

Besides, studies analyzing the role of institutions have of late been receiving special attention in natural resource management (Mokhahlane, 2009; Kirkland, Hunter, \& Twine, 2005), marketing management and agricultural production costs (Coase, 1992; North, 1993; Lal, 1999; Jari \& Fraser, 2009). An integrated, holistic approach that seeks to address agricultural challenges should therefore be viewed as that which includes institutional factor 
analysis on specific agricultural enterprises with special reference to both production and marketing outcomes. Rightly observed, when smallholder farmers are faced with high transaction costs they resort to producing mainly for home consumption (World Food Programme, 2009), although Randela (2005) has noted that the size of a household influences decision making on what and how much to produce. In addition to the interdependent nature of production and marketing institutions claimed by Coase (1992), a number of 'new', emerging institutional factors call for special attention.

In South Africa it has been claimed that developing markets for smallholder farmers can significantly attract them into mainstream formal marketing, with positive implications for production (Jacobs, 2008; Jari \& Fraser, 2009; Chikazunga \& Paradza, 2012; Ferris et al., 2014). A linkage of the working mechanism of production and market institutions is no doubt necessary in this regard. As North (1993) and IFPRI [International Food Policy and Research Institute] (2006) assert, economists still know very little about the dynamics of institutional changes. In support of this, Hou and Smith (2009) cautioned that the effects of informal norms (as a bridge between formal rules and governmental policy outcome) should not easily be undermined for positive policy reform. Evidently, the dynamics of informal norms are not easy to understand as they take time to change and the very same formal rules themselves (Hou \& Smith., 2009; Van Schalkwyk et al., 2012) are implemented via informal norms based on their interpretation by policy makers or government officials.

For South Africa where a number of policy shifts have occurred since 1994 aimed at uplifting the previously deprived Black farmers, these considerations assume exceptional significance. Such policy shifts included with them some programmes such as market deregulation, Land Redistribution for Agricultural Development and its successor schemes and programmes, the programme of black economic empowerment in agriculture known as Agri-BEE, the Comprehensive Agricultural Support Programme (CASP) and Micro-Agricultural Finance of South Africa (MAFISA), to name just a few. In one way or the other, they were all aimed at increasing production, productivity and market access for smallholder farmers. Why progress has remained slow and at inadequate levels is sufficiently confounding that urgent response is mandatory. At the same time, policy makers have to grapple with new issues such as the impact of climatic change, forces of international trade due to globalization some of which have triggered off the rising food prices that came to a head in 2008 and still continuing, despite a slight respite a few years ago. There is no denying that South Africa's smallholder farmers are more than ever faced with high risks and uncertainty both in production and marketing.

Besides, the influence of "interaction" of proposed policy reforms and evolving informal rules and norms have most probably retarded progress in smallholder development initiatives. Perhaps the pace at which the formal rules change is not properly aligned with the rate of change in the informal norms: a misalignment which has the tendency to disturb the institutional interdependency. The rest of this paper describes the project area, and presents the framework for the analysis before turning to the methodology and procedures followed in conducting the study. The paper then presents the results of the analysis with respect to the conception, management arrangements, operational modalities, asset ownership, and the nature of the relationship with governmental structures. Conclusions are drawn from these and the paper winds up with a set of recommendations.

\subsection{Description of the Study Area}

The study was carried out in the Lovedale1 \& Lovedale2 Vegetable Cooperatives, Nompumelelo Farmers Association, Lower Gqumahashe vegetable Cooperative, Somxada Food Security Association and the Sigabuliamatyathenga Vegetable Cooperative of Alice town in the Nkonkobe Local Municipality. The Nkonkobe Local Municipality falls under Amatole District Municipality of the Eastern Cape Province. Alice, a small town where UFH is situated, lies between latitude $32^{\circ} 56^{\prime}$ South and longitude $26^{\circ} 50^{\prime}$ East in southern South Africa in Eastern Cape Province. Alice town, where the six projects investigated are situated, is about 120 kilometers northwest of East London. Approximately $74 \%$ of the people living within Nkonkobe Local Municipality area are highly affected by poverty (Nkonkobe Municipality, 2009). The majority of the population, approximately $61 \%$, resides in rural areas, while as many as $20 \%$ of the population resides in farms and scattered settlements (Nkonkobe Municipality, 2009). Alice has a population 65472 individuals. The climate varies from hot in summer to extreme cold in winter with heavy frost and snowfall along the hilly areas. Average annual rainfall is $640 \mathrm{~mm}$, and most rain falls during the summer months from October to March, with frost and sometimes snow in winter. Mean maximum monthly temperatures range from $4{ }^{\circ} \mathrm{C}$ in July to $38{ }^{\circ} \mathrm{C}$ in February. Most of the roads linking the rural settlements are generally in poor conditions. The vegetation type is mostly Thorn Bush veld dominated by acacia Karroo species. 


\subsection{Framework for the Study}

The study entailed both qualitative and quantitative approaches. The objective was to seek an explanation outside conventional production economics for the sluggish performance of the vegetable production of smallholder farmers that perpetuates their poverty and food insecurity. The main reason to look outside conventional economics research principles and concepts is that a large body of research already exists which have failed to come up with adequate explanations for the paradox of the unrelenting poverty despite the clear and unmistakable emphasis that has been placed on rural development, community empowerment, poverty alleviation and rural employment. There clearly must be issues that have escaped the attention of conventional and neo-classical economics which are influential enough to sustain the current disadvantages.

The new institutional economics has been helpful in filling the conceptual gap in situations such as this. Some of the distinguishing characteristics of this approach include the range of variables that are modeled that are often calibrated on the basis of qualitative attributes. This paper therefore assumes a model of economic performance of vegetable farms that is heavily influenced by such qualitative attributes as management capabilities through committee involvement in production and marketing decisions, the membership of farming groups, extension contacts, among others. This perspective incorporates the transactions cost idea of Coase (1992) in which the cost of doing business is seen as a binding constraint. This is no true than in the smallholder contexts that characterize the former independent homelands where poverty is rife and even the most basic services can be inaccessible to the small farmer.

\section{Methods}

Data were collected using structured questionnaire. Farmers in six vegetable projects were interviewed in respect to institutional factors influencing vegetable production in the study area. In order to ensure that all questions were attended to by the respondents, the personal interview approach was used.

\subsection{Sampling Techniques and Designs}

The purposive sampling design which was used is a non-probability sampling method whereby the researcher purposively interviews individuals meeting the criteria of interest with the hope that they will provide an indepth information required for the research project (Leedy \& Ormrod, 2005). To remove the element of bias, particularly given the small size of the total farming population in that category, all participating farmers in each project were interviewed (i.e. 5 from Lovdale1, 6 from Lovedale2, 5 from Sigabuliamatythenga, 13 from Somxada, 14 from Nompumelelo and 19 from Gqumahashe).

\subsection{Data Analysis}

Data were coded in Microsoft Excel and then exported into SPSS (version 19) for analysis. In addition to the descriptive analysis to profile the smallholders and their socio-economic characteristics and production and marketing environments, the binary logistic regression operation was performed to test how institutional factors influence farmers' main reasons of producing vegetables.

Binary logistic regression is useful when a dependent variable is dichotomous (Chan, 2005). The model, according to Liao (1994), has only two categories in the endogenous variable resulting from a number of categorical predictor variables. The binary regression model has been widely used in a number of fields including social sciences when investigating dichotomous response (Long, 1997). In the study area, it is assumed that a smallholder farmer is faced with two choices subject to institutional arrangement. A smallholder farmer strives to maximize his/her utility by either producing vegetables mainly for sale (considered to be fully commercialized) or for both sale and consumption (considered partial commercialized) subject to the prevailing institutional arrangement.

Using the binary logit model, Darroch and Clover (2005) also determined factors affecting the survival, growth and success of small-medium and agribusiness. Mohammed and Ortman (2005) had also used the binary regression model when investigating whether or not commercial dairy farmers were insuring their livestock. The model employed in this study tests the probability that a smallholder farmer is influenced by institutional factors to either produce vegetable for both sale and consumption or solely for sale. Thus, the binary response is set up which defines $\mathrm{Y}=1$ for situations where a farmer produced vegetables for both consumption and sale and $\mathrm{Y}=0$ where a farmer produced solely for sale. The model specification can then be written as shown in equation 1.

$$
\begin{aligned}
& \operatorname{In}(Y 1)=\beta 0+\beta 1 x 1+\beta 2 x 2 \ldots \beta n x n \\
& \operatorname{In}(Y 0)=\beta 0+\beta 1 x 1+\beta 2 x 2 \ldots \beta n x n
\end{aligned}
$$

As shown in Equations (1) and (2), there are two probabilities with $Y 0$ denoting the lower response category 
(Vegetable production mainly for sale) and $\mathrm{Y}_{1}$ representing the higher response category being when a smallholder is producing for both sale and consumption. Both equations present the outcome of the logit transformation of odd ratios which can compactly be represented as:

$$
\operatorname{In}(Y 0 / Y 1)=\beta 0+\beta 1 x 1+\beta 2 \times 2 \ldots \beta n x n
$$

Equation (3) allows for its estimation as a linear model for which the following definitions apply:

$\beta 0=$ the constant or intercept term of the regression model; $\beta 1, \beta 2, \beta n=$ the regression coefficients of the individual predictor variables; $x 1+x 2 \ldots x n=$ Explanatory variables.

Table 1 depicts the variables included in the model and the expected sign of such variables as they influence the dependent variable.

Table 1. Summary of modeled explanatory variables

\begin{tabular}{llll}
\hline Variable name & Variable label & Coding & expected sign \\
\hline Management committee meeting frequency & MCMF & 0 if more frequent, 1 otherwise & $+/-$ \\
Management committee strengths & MCS & 0 if many, 1 otherwise & + \\
Management committees weakness & MCW & 0 if no, 1 otherwise & $+/-$ \\
Idea of association formation & IAF & 0 if participants, 1 otherwise & $+/-$ \\
Land ownership & LO & 0 if participants, 1 otherwise & + \\
Working strategy in the field & WSF & 0 if collectively, 1 otherwise & + \\
marketing strategy & WSM & 0 if collectively, 1 otherwise & $+/-$ \\
Presence of extension service & PES & 0 if yes, 1 otherwise & $+/-$ \\
conditions of roads & CR & 0 good, 1 otherwise & + \\
Relationship to the municipality & RM & 0 if good, 1 otherwise & - \\
\hline
\end{tabular}

When the above variables are fitted in the model in Equation (1), a typical regression model would be as shown in Equation 4:

$$
\operatorname{In}(Y 0 / Y 1)=\beta 0+\beta 1 M C M F+\beta 2 M C S+\beta 3 M C W+\beta 4 I A F+\beta 5 L O+\beta 6 W S F+\beta 7 W S M+\beta 8 P E S+\beta 9 C R+\beta 10 R M
$$

Where:

$Y 0=$ Vegetable production mainly for sale; $Y 1=$ vegetable production for both consumption and sale; $\beta 0=$ Constant; $\beta 0 \ldots \beta 10=$ Co-variants.

\section{Results and Discussion}

The results are presented separately for the descriptive analysis and the inferential analysis.

\subsection{Results of the Descriptive Analysis}

Characteristics of sampled household such as gender, age, marital status and educational levels attained were analyzed. The rationale for the inclusion of the demographic features is that demographic characteristics of households are essential when analyzing economic data because such factors would influence the households' economic behavior. Demographic features of sampled household are most likely to influence their production levels and as such are relevant. Table 2 exhibits the demographic characteristics of the sampled households in the study area. 
Table 2. Distribution by demographic characteristics of the sampled households in the study area $(n=62)$

\begin{tabular}{|c|c|c|c|c|c|c|c|}
\hline \multirow{2}{*}{ Variable } & \multirow{2}{*}{$\begin{array}{l}\text { Siga } \\
\text { Respondents (\%) }\end{array}$} & \multirow{2}{*}{$\begin{array}{l}\text { Lov1 } \\
\text { Respondents (\%) }\end{array}$} & \multirow{2}{*}{$\begin{array}{l}\text { Lov } 2 \\
\text { Respondents (\%) }\end{array}$} & \multirow{2}{*}{$\begin{array}{l}\text { Somxa } \\
\text { Respondents (\%) }\end{array}$} & \multirow{2}{*}{$\begin{array}{l}\text { Nompu } \\
\text { Respondents (\%) }\end{array}$} & \multirow{2}{*}{$\begin{array}{l}\text { Gquma } \\
\text { Respondents (\%) }\end{array}$} & \multirow{2}{*}{ All projects } \\
\hline & & & & & & & \\
\hline \multicolumn{8}{|l|}{ Age } \\
\hline $0-35$ & 40 & 0 & 0 & 15 & 14 & 11 & 13 \\
\hline $36-45$ & 20 & 33 & 40 & 54 & 22 & 5 & 26 \\
\hline $46-55$ & 40 & 33 & 60 & 15 & 0 & 21 & 19 \\
\hline $56-65$ & 0 & 17 & 0 & 16 & 7 & 15 & 13 \\
\hline $66-75$ & 0 & 17 & 0 & 0 & 46 & 37 & 23 \\
\hline \multirow[t]{2}{*}{$>75$} & 0 & 0 & 0 & 0 & 14 & 11 & 6 \\
\hline & 100 & 100 & 100 & 100 & 100 & 100 & 100 \\
\hline \multicolumn{8}{|l|}{ Gender } \\
\hline Male & 100 & 100 & 100 & 31 & 64 & 79 & 71 \\
\hline \multirow[t]{2}{*}{ Female } & 0 & 0 & 0 & 69 & 36 & 21 & 29 \\
\hline & 100 & 100 & 100 & 100 & 100 & 100 & 100 \\
\hline \multicolumn{8}{|c|}{ Marital status } \\
\hline Married & 40 & 67 & 60 & 36 & 64 & 79 & 61 \\
\hline Single & 60 & 33 & 40 & 36 & 29 & 11 & 29 \\
\hline Widowed & 0 & 0 & 0 & 23 & 7 & 5 & 8 \\
\hline \multirow[t]{2}{*}{ Divorced } & 0 & 0 & 0 & 0 & 0 & 5 & 2 \\
\hline & 100 & 100 & 100 & 100 & 100 & 100 & 100 \\
\hline \multicolumn{8}{|c|}{ Educational level } \\
\hline Primary & 0 & 50 & 0 & 39 & 43 & 26 & 31 \\
\hline Secondary & 20 & 16 & 0 & 8 & 43 & 32 & 24 \\
\hline High school & 60 & 34 & 100 & 53 & 7 & 37 & 40 \\
\hline \multirow[t]{2}{*}{ Tertiary } & 20 & 0 & 0 & 0 & 7 & 5 & 5 \\
\hline & 100 & 100 & 100 & 100 & 100 & 100 & 100 \\
\hline \multicolumn{8}{|l|}{ Occupation } \\
\hline Farmer & 80 & 100 & 100 & 100 & 100 & 95 & 90 \\
\hline Teacher & 0 & 0 & 0 & 0 & 0 & 0 & 5 \\
\hline Security & 0 & 0 & 0 & 0 & 0 & 0 & 3 \\
\hline \multirow[t]{2}{*}{ Student } & 20 & 0 & 0 & 0 & 0 & 0 & 2 \\
\hline & 100 & 100 & 100 & 100 & 100 & 100 & 100 \\
\hline
\end{tabular}

Source: Field Survey (2011).

The six projects investigated were Siga, Lov1, Lov2, Somxa, Nompu and Gquma. Comparing the age distribution across all projects, Nompu and Gquma are dominated by much older farmers in the 66-75 years who comprise $43 \%$ and $37 \%$ of all the farmers, respectively. The results also show that it was mainly in Nompu and Gquma where the age distributions by respondents have been evenly distributed, implying that not only old aged persons engage in vegetable production. Interestingly, male farmers represented a higher percentage $(71 \%)$ of the projects participants. This finding may most probably be explained by a high retrenchment rate of men from the mining sector in South Africa. The majority of sampled farmers were married except for Siga where $60 \%$ of farmers were single. All in all, $61 \%$ of the project participants were married as shown in Table 2.

The results presented in Table 2 further show that most project participants (40\%) had a high school education. According to Table 2, farming plays a central role in farmers' livelihoods as $90 \%$ of all the farmers surveyed were fully employed in farming. This finding can best be explained by the fact that in Nkonkobe Municipality, unemployment rate is high (Nkonkobe Municipality, 2009). The Organizational structure of the projects was also 
investigated. By organizational structure, the study investigated whether or not the projects members had the management committees that oversaw the projects' operation and took decisions about resource allocation and distribution of tasks and responsibilities. The descriptive analysis on organizational structure of the projects revealed some interesting results on strengths and weakness from the point of view of the projects participants. Table 3 presents results of the values of the strengths and weakness of the management committees of the enumerated projects.

Table 3. Distribution by strengths and weakness of management committees in six projects

\begin{tabular}{lllllll}
\hline Variable & Siga \% & Lov 1 \% & Lov 2\% & Somxa \% & Nompu \% & Gquma \% \\
\hline Motivation to members & 40 & 0 & 40 & 15 & 57 & 5 \\
Motivation and Disputes resolutions among members & 60 & 100 & 60 & 39 & 36 & 68 \\
Good communication flow & 0 & 0 & 0 & 8 & 0 & 0 \\
No strengths & 0 & 0 & 0 & 39 & 7 & 26 \\
& 100 & 100 & 100 & 100 & 100 & 100 \\
\hline Variable & Siga \% & Lov1 \% & Lov2 \% & Somxa $\%$ & Nompu \% & Gquma \% \\
\hline Poor communication flow & 0 & 0 & 0 & 0 & 0 & 53 \\
Lack of negotiation power for formal markets access & 80 & 33 & 80 & 31 & 7 & 37 \\
Lack of commitment & 0 & 0 & 0 & 15 & 14 & 0 \\
Failure to assist members & 0 & 17 & 0 & 31 & 29 & 10 \\
No weakness & 20 & 50 & 20 & 23 & 50 & 0 \\
& 100 & 100 & 100 & 100 & 100 & 100
\end{tabular}

Source: Field Survey (2011).

The findings show that the management committees motivated members in all six projects. In general, motivation and dispute resolution amongst the project members seem to have been the common strengths reported in all six projects This finding seems to support the evidence from the literature that local communities have their own complex informal mechanisms for resolving their conflicts (IFPRI, 2006). Following on the strengths of the management, the survey farmers were also asked to pinpoint the weakness (if any) of their management committees. Table 3 presents the distribution of the respondents by the weaknesses of their respective management committees.

Based on respondents' perception of the weakness of their management committees, the research findings show that lack of negotiation power to lobby formal markets seems to be common across all projects. The evidence from the literature, that institutional factors have tended to constrain smallholder's access to formal markets, is supported by this finding (Jacobs, 2008; Magingxa, Zerihun, \& van Schalkwyk, 2009; Jari \& Fraser, 2009). More weaknesses than strengths were identified by farmers in each project.

In an attempt to predict the sustainability of each project, the survey households were asked where the idea of forming the cooperatives came from. In Siga, 100\% of farmers reported that the idea came from members themselves. In Lov1 and Lov2, 100\% of respondents mentioned that University of Fort Hare pioneered the formation of the association. ARDRI (Agriculture and Rural Development Research Institute at the University of Fort Hare) was reported (by 100\% of the respondents) as the body that had broached the idea of cooperative formation in Gquma. In Nompu and Somxa, the survey households provided different responses on who brought the idea of project formation. The issues of who pioneered farmer's association projects seem to be critical as revealed by the binary logistic results and as such may open the scope for further research to determine the productivity and sustainability of such projects.

Given the fact that Food and Agricultural Organization (FAO) (2009) argues that ownership of farm land would affect the sustainability of the land use, the survey farmers were asked how they accessed the land on which they farm. Generally, the findings revealed that most of the land used for vegetable production is not owned by the project participants. Figure 1 illustrates different ways through which land was accessed in all projects. 


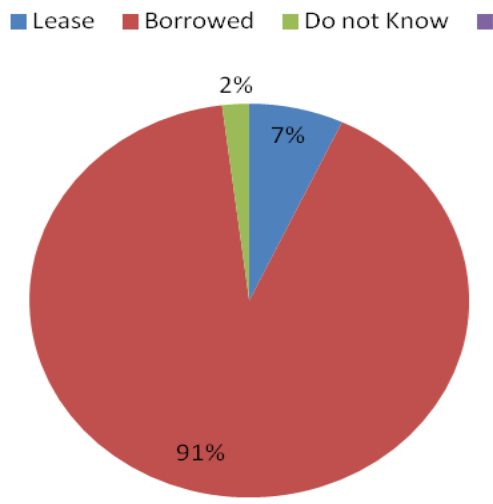

Figure 1. Land acquisition strategy in six vegetable projects $(n=62)$

Source: Field Survey (2011).

With regard to land ownership and or land access, the research findings, indicate that the land reform programme, in particular the tenure systems, has not yet fully addressed the problems of the previously deprived black smallholder farmers in South Africa.

\subsection{Empirical Results of the Binary Logistic Regression}

From the study, it is hypothesized that smallholder farmers are influenced by institutional factors in vegetable production. This assumption implies that a smallholder farmer aims at maximizing his or her utility by either producing vegetable mainly for sale and consumption or mainly for sales subject to institutional constraints in Nkonkobe Local Municipality. Nine institutional variables and one technical variable (CR) were factored in a binary logistic regression to test their influence on farmer's main reason for producing vegetables.

The variables modeled include: management committee meeting frequency (MCMF), Management committee strength (MCS), management committee weakness (MCW), idea of association formation (IAF), land ownership (LO), working strategy on production in the field (WSF), working strategy in marketing (WSM), presence of an extension service (PES), Condition of roads (CR) and relationship to the Municipality (RM) by the survey farmers. Seven of these variables were significant at 5 percent alpha level in influencing the farmers 'main reason for vegetable production (see Table 4). The higher the value of the odds ratio for each variable in Table 4, the higher probability that such a variable would change to either direction (i.e. vegetable production mainly for sale or for both consumption and sale) if adjusted otherwise.

Table 4. Results of the logistic regression analysis

\begin{tabular}{llllll}
\hline Parameter & Coef. & S.E. & Wald & P-value & Exp (B) \\
\hline Constant & -10.290 & 5.184 & 7.102 & 0.47 & 0.000 \\
Management Committees Meeting frequency & -5.752 & 2.158 & 1.397 & $0.008^{* *}$ & 0.003 \\
Manangement Committee Strengths & 0.612 & 0.517 & 2.604 & 0.237 & 1.843 \\
Management Committee Weakness & 0.37 & 0.333 & 3.860 & 0.107 & 1.710 \\
Idea of association formation & 0.971 & 0.494 & 4.707 & $0.049^{* *}$ & 2.640 \\
Land Ownership & 0.889 & 0.410 & 9.838 & $0.030^{* *}$ & 2.432 \\
Working strategy in the field & 6.222 & 1.984 & 5.249 & $0.002^{* *}$ & 503.858 \\
Working Strategy Marketing & -2.591 & 1.131 & 3.888 & $0.022^{* *}$ & 0.075 \\
Presence of Extension Services & 2.855 & 1.448 & 1.539 & $0.049^{* *}$ & 17.373 \\
Condition of Roads & -1.484 & 1.196 & 4.027 & 0.215 & 0.227 \\
Relationship with the Local Municipality & 1.310 & 0.653 & 3.940 & $0.045^{* *}$ & 3.707 \\
\hline
\end{tabular}

Note. Significance tests were carried out at the $5 \%$ level.

Source: Computed from Field Survey Data (2011). 
$\operatorname{In}($ Mainly for sale/For sale \& consumption $)=$

$$
\begin{aligned}
& 10.290-5.752(M C M F)+0.612(M C S)+0.537(M C W)+0.971(I A F)+0.889(L O)+6.222(M S F)-2.591(\text { WSM }) \\
& +2.855(P E S)-1.484(C R)+1.310 R M
\end{aligned}
$$

\subsection{Frequency of Management Committee Meetings}

Frequency of the management committees meeting seems to have a strong influence on farmers' main reason of producing vegetables. The logistic results presented in Table 4 reveal that an increase in the frequency of the management meeting can significantly influence farmers who work in projects or associations and shift their main aim of vegetable production towards the lower base response variable (i.e. mainly for sale). This demonstrates the urgency to disseminate information on cultural practices and also capacitate farmers to acquire skills and know-how. It is however important to note that despite the significance of this variable in influencing the farmers' decision in vegetable production, the complementary nature of other market institutions is crucial.

\subsection{Idea of Association Formation}

The results indicated that there is a weak relationship between the main reason farmers produce vegetables and the initiator of the project. From Table 4, the logistic results show that if the ideas of project formation came from the project participants themselves, they are more likely toalign their production decisions towards the high base response variable (i.e. vegetable production for both sales and consumption).

This finding shows that in situations where farmers are engaged in project identification and formulation, they tend to be flexible in planning the production decisions subject to resources, technical and institutional constraints given the fact that two options are possible in a high base response category. This finding may best explain why imposed or top-down projects have had little successes in improving livelihoods. This is likely the case when participants are supposed to work within the expectations of project pioneer(s). As with other variables, it must be acknowledged that a farmer's main reason to produce vegetables could also be influenced by other factors such as market access and family size (Randela, 2005; WFP, 2009), further highlighting the need to adopt a broad analytical perspective that combines conventional neo-classical tools and institutional economics.

\subsection{Land Ownership}

Land ownership seems to have a strong influence on farmer's main reason of vegetable production. At 5 percent significance level, the results in Table 4 show that if farmers do not have title to the land they farm, they are likely to shift their production decision towards a high response variable being for both home consumption and sale. In this respect, even if the essential infrastructure required for commercialization were to be put in place, it could have still been somehow hard for smallholder farmers to be fully commercialized owing to the lack of land ownership. When farmers lack title to the land used for farming, they resort to making short term production decisions since they could feel that they are not stable on such land (FAO, 2009). The results in relation to land ownership in this regard, suggest that whether or not a farmer has access to the market, he could be fully commercialized when he holds title to the land used.

\subsection{Working Strategy in the Field}

Farmers working collectively can pool together some farm resources thereby securing more produce for the market (Chikazunga, 2011). The prior expectation was that positive relationship between vegetable production for sale and the collectively operating projects would exist. However, the results presented in Table 4 revealed that famers who work collectively are influenced to produce vegetables for both sales as well as consumption. Given the high significance level of this variable $(p=0.002)$, the result suggests that when farmers work collectively in the field there is greater likelihood that they would produce vegetable for both sale and consumption, pointing up the crucial food security implications. It is more likely that this occurs as people working together have different aspirations which will most likely reinforce each other (Brown, 2000).

\subsection{Marketing Strategy}

It is argued that collective marketing improves market access by smallholder farmers (Jacobs, 2008; Jari \& Fraser, 2009). The -2.591 coefficient of this variable in the logistic model represents the likelihood that collective marketing would influence smallholder farmers to shift their main reason for producing vegetables towards sales. The significance of this variable $(p=0.02)$ in influencing farmers main reason for producing vegetables clearly justifies the strengths of the variable and show that farmers marketing their produce individually are less likely to produce mainly for sale. Hence, this finding supports that of IFPRI (2006) postulating that collective action helps farmers access markets which they individually could not access. The results however, indicate that those farmers who market their produce individually would most probably shift 
also produce for consumption because the degree of market access is minimized by the higher transport costs and lower social capital they experience (Chikazunga, 2007; Jari \& Fraser, 2009).

\subsection{Presence of an Extension Service}

Based on the results of the logistic regression presented in Table 4, the relationship seems to exist between farmers' main reason for vegetable production and the presence of an extension service that delivers extension messages to farmers. The delivery of an extension service seems to influence farmers' main reason for the production of vegetables mainly for sale and consumption given the coefficient of 2.855 . The implication of this coefficient in the logistic regression is mainly reflected in the strengths of this variable which influences the consumption as well as the sale of vegetables either way. In order words, the absence of an extension service would influence farmers to produce vegetable mainly for sale. It is most likely that the current extension services provided to farmers are mostly oriented to subsistence and food security assurance, with farmers selling only the surplus. The fact that FAO (2007) has discovered that the extension workers rarely if ever plan the work along marketing challenges faced by farmers may best explain why it seems from the results that the absence of extension service would influence farmers produce for both sale and consumption. Nevertheless, it cannot be concluded with some certainty that the absence of extension services would always influence farmers to produce vegetables for both sale and consumption. In practice, what this result implies is that the current extension service provided to farmers needs to be reviewed in such a way that it orientates the smallholder farmers more strongly to marketing. Hence, it is more likely that most of the smallholder farmers would be fully commercialized (i.e. producing vegetables mainly for sales) given an enabling market environment, ceteris paribus.

\subsection{Reasons for the Unique Relationship with the Municipality}

The results presented in Table 4 on reasons for the kind of relationship (normally based on perceptions as informal norms) of the project participants and the local Municipality influenced their main vegetable production decisions in the study area. The logistic results show that the current relationship of the project participants and the local municipality influenced them to produce vegetables for sale and consumption at $(p=0.045)$. Given its significance in the model, this variable (based on perceptions) if adjusted to the other direction could influence farmers to produce mainly for sale. This is especially true in view of the fact that Hou and Smith (2009) cautioned that the influence of informal norms, as a bridge between formal rules and policy outcome, should not be undermined. It must, however, be noted that changing of norms and perception would require strategic approaches, such as provision of incentives or penalties, given the fact that they take time to change.

\section{Conclusion}

In the Nkonkobe Local Municipality nine institutional factors were identified and analyzed on the basis of their influence on small-scale vegetable producers' decision. Of all such factors identified, the frequency of the management committees meeting was significant in shaping the farmers' decisions in vegetable production. As the management committee convenes meetings frequently, there are increased chances that project member would produce mainly for sale. An issue of who brought up the idea of project formation was also significant to the extent that it influenced farmers to produce vegetables for sale and consumption. Given the fact that there was confusion as to who pioneered association formation in most projects, it is most likely that commercialization policies (i.e. as hypothesized to represent mainly for sale) are likely to be a success if farmers initiate their own projects. On the other hand, land ownership in the study area seemed to be a subject of concern as the majority of farmers (see Figure 1) were farming on leased land. The inferential statistics suggests that in the absence of secure land tenure, it is most unlikely that farmers would be fully commercialized (i.e. production mainly for sale). Similarly, the results of the study revealed that different types of collective action must be noted in policy formulation and/or recommendations. This is especially the case in view of the fact that farmers who worked collectively in production were influenced to produce for both sale and consumption but those who marketed the produce collectively were influenced to make production decisions that are inclined more towards sales.

Consequently an argument that collective action in marketing can help make farmers access more rewarding markets seems plausible (IFPRI, 2006; Jari \& Fraser, 2009). Presence of an extension service to the farmers does not necessarily mean farmers would be influenced to produce mainly for sale. In the projects investigated, most farmers received an extension service but such a service influenced them to produce for both sale and consumption. This could most probably be explained by the fact that extension workers seldom address marketing opportunities and challenges to farmers (WFP, 2009). The relationships with the local municipality influenced farmers' production and marketing. Although such a relationship between the municipality and 
farmers is largely influenced by differing perceptions and political affiliations, the research finding suggests that if the very same perceptions and political positions change in the opposite direction, it is most likely that farmers would produce vegetables mainly for sale or be fully commercialized. Therefore, strategies proposed in linking smallholder farmers to profitable markets should take into account the role the municipality could play in this regard. Perhaps, this is most likely the case given that the Municipality has responsibility for the provision of basic market access requisites such as roads and market information among others.

Given the fact that institutional factors influence production and marketing costs (Coase, 1992; North, 1993; Lal, 1999), it is natural to expect that they would influence farmers' decisions to either produce for sale, consumption or for both. This is especially true as discovered by WFP (2009) that when smallholder farmers fail to access more profitable markets, they normally resort to produce mainly for home consumption.

Nevertheless, Monde (2003) and Randela (2005) had cautioned that own agricultural production for home consumption should not be easily undermined as it contributes to improved household food security. The fact that most of the surveyed farmers did not have secure tenure rights and that the majority did not receive consistent visits from the extension service could best explain why some land was left idle (i.e in Somxa and Gquma for instance). Besides, sustainable and efficient land resources use is compromised when individuals lack secure tenure rights on the land use (Makosholo, 2005; FAO, 2009). This raises a serious concern as about $90 \%$ of the survey farmers were using leased land across all six projects.

The problem statement for this investigation was that the institutional factors influence the way individuals interact in vegetable production and hence economic activity. The problem that needed to be examined was whether the existing or imposed formal rules on project participants do influence them to make production decisions that make them derive more benefits on sustainable and efficient basis in vegetable production.

A number of institutional aspects identified influenced decision making in vegetable production by the survey farmers and it was observed that a limitation of one or more of the identified institutional factors is likely to outweigh the positive impact of the other institutional factors. Owing to the fact that most of the surveyed farmers confirmed that they lacked ownership of land, clearly signals retarded development and inappropriate land use practices. Factored in a logistic model, land ownership was significant such that the results showed that in the face of lack of ownership, farmers are unlikely to be fully commercialized. Provision of title deeds to farmers is necessary for increased vegetable production and long-term productivity of farm lands. Similarly, the fact that the farmers who had relatively large land or plot sizes such as those in Somxa and Gquma (i.e. where some land was left idle during 2010/2011 growing season) explains that institutional support is needed and that exploiting the interdependency of institutional factors as well as the availability and suitability of the resources is crucial to smallholder development.

Contract farming (though did not exist amongst all survey farmers) is crucial as a tool for enhancing smallholder farmers' market access based on the evidence from the literature. It encourages commercialization of agriculture and promotes the development of entrepreneurial skills among smallholder farmers (Kirsten \& Satorius, 2002).

Similarly, access to and use of credit by the survey farmers was investigated. None of the farmers in the study area had used credit. Given the evidence from the literature (Hoff \& Stiglitz, 1990; Swinnem \& Gow, 1999; Seibel, 2000; FAO, 2009) and the observations during field survey in 2011, the use of credit by smallholder farmers was low. In this regard it is recommended that access to credit and its use (i.e. where farmers do not have alternative means of cash) could help farmers address problems of production inputs such as seeds, fertilizers, including irrigations facilities, storage facilities and transport (Salami, Kamara, \& Brixiova , 2010; de Klerk et al., 2013).

However, access to credit should be made on interest rate that smallholder farmers can afford while at the same time earning some income. It is in this sense that one notes that market access correlates with credit access because if farmers do not have the market to sell the produce so as to repay the loan, then the financial institutions are reluctant to lend. The same applies to farmers who do not have collateral. The banks or financial institutions would be reluctant to issue loans (FAO, 2009). Even those smallholder farmers who have collateral must be linked to markets (Jacobs, 2008). Such links would lead tomutual benefits for both the financial institutions and clients or farmers.

Finally, the analysis and discussion of the results have conclusively shown that when farmers are constrained by some institutional factors, the positive outcome of the existing institutional factors on smallholder farmers may be unrealizable. However, for increased vegetable production in the Nkonkobe Local Municipality, a more involved immediate reconsideration of weak institutional factors identified is crucial. The availability and suitability of the physical resource attributes such as land and infrastructure are crucial in complementing the 
effectiveness of institutional factors. Given the foregoing discussion, it is concluded that some institutional factors need some modifications accordingly so as to complement the effectiveness of the proposed agricultural policies in the study area. There is a need for institutional change more especially when development practitioners and farmers claim the commercialization of agriculture in the Nkonkobe Municipality.

\section{Acknowledgements}

The authors wish to express gratitude to the survey farmers, the Water Research Commission, N. Monde, N. Lebitsa, and N. Madolo, for their respective roles in the original study on which this paper is based.

\section{References}

Adebiyi, M. A., \& Obasa, B. B. (2004). Institutional framework, interest rate policy and financing of Nigeria manufacturing sub-sector. Retrieved April 10, 2011, from http://www.tips.org.za/files/institutional_framework_interes_rate_policy_obasa_adbiyi.pdf

Brown, L. R. (2000). In a search for a system model for decision making behaviour of first Generation black commercial farmers in Border-keiskamahooek Region of Eastern Cape Province (Unpublished PhD Thesis). University of Fort Hare.

Chan, Y. H. (2005). Multinomial logistic regression analysis. Singapore Medical Journal, 46(6), 259-269. Retrieved April 2, 2011, from http://www.sma.org.sg/smj/4606/4606bs1.pdf

Chikazunga, D. (2011). Collective action and smallholder farmers' participation in agricultural markets. Retrieved October 14, 2011, from http://www.findavenue.co.za/AEASA/Presentations/Chikazunga\%202.pdf

Chikazunga, D., \& Paradza, G. (2012). Smallholder farming: A panacea for employment creation and enterprise development in South Africa? Lessons from the Pro-Poor Value Chain Governance Project in Limpopo Province. Strategies to overcome poverty and inequality: Towards Carnegie III.

Coase, R. H. (1992). The Institutional structure of Production. The American Economic Review, 82(4), 713-719.

Darroch, M. A. G., \& Clover, T. A. (2005). Factors Affecting the Survival, Growth and Success of Small, Medium and Micro Agribusiness in KwaZulu-Natal, South Africa. International food and agribusiness management association world foodand agribusiness symposium (p. 27). Chicago, USA.

de Klerk, M., Fraser, F., \& Fullerton, K. (2013). The Status of Agricultural and Rural Finance in South Africa. FinMark Trust.

FAO. (2007). Approaches to linking producers to markets: A review of experiences to date. Food and Agricultural Organisational of theUnited Nations, Rome, Italy.

FAO. (2009). Rethinking public policy in agriculture: Lessons from distant and recent history. Cambridge, London.

Ferris, S., Robbins, P., Best, R., Seville, D., Buxton, A., Shriver, J., \& Wei, E. (2014). Linking Smallholder Farmers to Markets and the Implications for Extension and Advisory Services. MEAS Discussion Paper Series on Good Practices and Best Fit Approaches in Extension and Advisory Service Provision, Washington, USAID.

Flom, P. L. (2011). Multinomial and ordinal logistic regression using PROC LOGISTIC. Retrieved from April 9 , 2011, from http://www.nesug.org/proceedings/nesug05/an/an2.pdf

Greenberg, S. (2010). Status report on Land and Agricultural policy in South Africa. Research report 40.

Hoff, K., \& Stiglitz, J. (1990). Imperfect Information and Rural Credit Markets - Puzzles and Policy Perspectives. World Bank Economic Review, 4(3), 235-250. http://dx.doi.org/10.1093/wber/4.3.235

Hou, Y., \& Smith, D. L. (2009). Informal Norms as a Bridge between Formal Rules and Outcomes of Government Financial Operations: Evidence from State Balanced Budget Requirements. Journal of Public Administration Research and Theory, 20(3), 655-678. Retrieved from July 16, 2010, from http://jpart.oxfordjournals.org/content/20/3/655.short

IFPRI. (2006). Collective action and property rights for sustainable development: Understanding Collective Action. Retrieved from April 1, 2011, from http://www.ifpri.org/sites/default/files/pubs/2020/focus/focus11/focus11_02.pdf

Jacobs, P. (2008). Market Development and Smallholder Farmers-A Selective Literature Survey. Retrieved from April 14, 2010, from http://www.Scincedirect.com/science 
Jari, B., \& Fraser, G. (2009). An analysis of institutional and technical constraints influencing agricultural marketing amongst smallholder farmers in the Kat river valley, Eastern Cape, South Africa. African Journal of Agricultural Research, 11(4), 1129-1137.

Kirkland, T., Hunter, M., \& Twine, W. (2005). "The bush is no more”: Insights on Institutional Change and Natural Resource Availability in Rural South Africa. Working paper. University of Colorado at Boulder.

Kirsten, J., \& Satorius, K. (2002). Linking agribusiness and small-scale farmers in developing countries: Is there a new role for contract farming? Development Southern Africa, 19(4). http://dx.doi.org/10.1080/0376835022000019428

Lal, D. (1999). Culture, democracy and development: Role of formal and informal Institutions and development. Retrieved August 23, 2010, from http://www.imf.org/External/pubs/FT/seminar/1999/reforms/lal.htm

Leedy, P. D., \& Ormrod, J. E. (2005). Practical research. Planning and design. Pearson Merrill prentice hall-Ohio. USA.

Lekovic, V. (2011). Interaction of formal and informal institutions - impact on economic success. Facta Universitatis - Economics \& Organizations, 8(4), 357-370.

Liao, F. T. (1994). Interpreting Probability Models. Sage Publications Inc, New Delhi.

Long, J. S. (1997). Regression Models for Categorical and Limited Dependant Variables: Advanced Quantitative Techniques in the Social Sciences (Vol. 7). Sage Publications Inc, Thousand Oaks.

Magingxa, L., Zerihun, G., Alemu, \& van Schalkwyk, H. D. (2009). Factors influencing access to produce markets for smallholder irrigators in South Africa. Development Southern Africa, 26(1), 47-58. http://dx.doi.org/10.1080/03768350802640081

Makosholo, M. (2005). Comparative advantage of Long-term crops in Lesotho (MSc Thesis). University of Free State, South Africa.

Mohammed, M. A., \& Ortmann, G. F. (2005). Factors influencing Adoption of Livestock Insurance by Commercial Dairy Farmers in Three Zobatat of Eritrea. Agrekon, 44(2), 172-186. http://dx.doi.org/10.1080/03031853.2005.9523708

Monde, N. (2003). Household Food Security in Rural areas of Central Eastern Cape (PhD Thesis). University of Fort Hare

Mokhahlane, M. (2009). Institutional factors affecting the use of communal rangeland in the Eastern Cape Province of South Africa. MSc Thesis, University of Fort Hare, South Africa.

Motteux, N. (2001). The Development and Co-ordination of Catchment Fora through the empowerment of Rural Communities, Catchment Research Group. WRC Report K5/1014. Water Res. Commission, Pretoria.

Nel, E., \& Davies, J. (1999). Farming against the odds: An examination of the challenges facing farming and rural development in the Eastern Cape province of South Africa (p. 22). Department of Geography, Rhodes University, Grahamstown.

Nkonkobe Municipality. (2009). Nkonkobe Integrated Development Programme. Draft IDP Review 2011/12, The Honourable Mayor. Retrieved April 22, 2015, from http://mfma.treasury.gov.za/Documents/01.\%20Integrated\%20Development\%20Plans/2011-12/02.\%20Loc al\%20Municipalities/EC127\%20Nkonkobe/EC127\%20Nkonkobe\%20\%20IDP\%20-\%201112.pdf

North, D. (1993). Institutions, institutional change and economic performance. Cambridge: Cambridge University Press.

Pejovich, S. (1999). The Effects of the Interaction of Formal and Informal Institutions on Social Stability and Economic Development. Journal of Markets \& Morality, 2(2), 164-181.

Randela, R. (2005). Integration of emerging cotton farmers into the commercial agricultural economy (Unpublished $\mathrm{PhD}$ thesis). University of the Free State, Bloemfontein.

Salami, A., Kamara, A. B., \& Brixiova, Z. (2010). Smallholder Agriculture in East Africa: Trends, constraints and opportunities. The working paper. Retrieved May 6, 2011, from http://www.afdb.org/fileadmin/uploads/afdb/Documents/Publications/WORKING\%20105\%20\%20PDF\%2 0d.pdf

Schultz, T. (1964). Transformation of Traditional Agriculture. New Haven: Yale University Press. 
Seibel, H. D. (2000). Agricultural Development Banks: Close them or reform them. Finance and Development, 37(2), $\quad 1-4 . \quad$ Retrieved $\quad$ August $12, \quad 2011, \quad$ from http://www.imf.org/external/pubs/ft/fandd/2000/06/pdf/seibel.pdf

Swinnen, J. F. M., \& Gow, H. R. (1999). Agricultural credit problems and policies during the transition to a market economy in Central Eastern Europe. Food Policy, 24(1), 21-47. http://dx.doi.org/10.1016/S0306-9192(98)00067-0

Van Schalkwyk, H. D., Groenewald, J. A., Fraser, G. C. G., Obi, A., \& van Tilburg, A. (eds) (2012). Unlocking Markets to Smallholders - Lessons from South Africa. Series No. 10. Wageningen, Wageningen Academic Publishers and Mansholt Publications. http://dx.doi.org/10.3920/978-90-8686-168-2

WFP. (2009). Fighting hunger world wide: 3 ways to help smallholder farmers help themselves. World Food $\begin{array}{llll}\text { Programme. } & \text { Retrieved } & \text { 26, 2010, } & \text { from }\end{array}$ http://www.wfp.org/stories/3-ways-help-smallholder-farmers-help-themselves

Williamson, O. E. (2000). The New Institutional Economics: Taking Stock, Looking Ahead. Journal of Economic Literature, 38(3), 595-613. http://dx.doi.org/10.1257/jel.38.3.595

\section{Copyrights}

Copyright for this article is retained by the author(s), with first publication rights granted to the journal.

This is an open-access article distributed under the terms and conditions of the Creative Commons Attribution license (http://creativecommons.org/licenses/by/3.0/). 